ON

\title{
ETHER AND CHLOROFORM
}

$\mathbf{A S}$

AN AESTHETICS.

BY

J. WARRINGTON HAWARD, F.R.C.S., ASSISTANT SURGEON TO THE CHILDREN's HOSPITAL.

Read October 24th, 1871.

IT is sometimes useful to recall attention to neglected, or forgotten remedies or methods of treatment; and it was suggested to me a year ago, by Mr. Thomas Smith, that the statements and practice of American surgeons, and especially of Dr. Bigelow, seemed to show that ether vapour, as an anæsthetic, had been unduly and to our detriment neglected. I therefore commenced some investigations into the subject, and am desirous in this communication to offer some remarks upon the use of ether as an anæsthetic, and also some observations that $I$ have had the opportunity of making upon chloroform, used for the same purpose.

The reason for the almost complete substitution of chloroform for ether, as an anæsthetic in this country, is, I suppose, chiefly the greater potency of chloroform, and the ease and 
rapidity with which its effects can be obtained and regulated. But it should be remembered that when chloroform was introduced, the whole subject of anæsthetic inhalation was beginning to be better understood, and that its use was therefore commenced under more favorable auspices than ether ; and I cannot but think that its general adoption was in great part due to its having as an advocate, one of the indomitable energy of Dr. Simpson, and from the impression that arose from his first essay on the subject, that chloroform was a safer agent than ether.

I do not myself doubt that chloroform is in some respects more manageable and convenient than ether, but I think there can be no doubt also that it is more dangerous than ether, and that the danger arises much more suddenly, and is of a kind much more difficult to avoid and foresee than in ether. If therefore the administration of ether can be made, as I believe it can, almost as easy as that of chloroform, and if the effects for which we give it are equally well produced, it becomes a question we are bound to consider, how far we are justified, except in special instances such as I will allude to, in resorting to the more dangerous agent.

Moreover ether has some decided advantages over chloroform, besides its greater safety. As to the fact of the greater safety of ether, it is very difficult to obtain any reliable statistics, especially as in this country it is so seldom used. But it is given largely in America and some parts of France, and Dr. Andrews states ('New York Med. Journ.,' June, 1870 , p. 443) that in 92,815 cases in which ether was given, in only 4 was it fatal, i.e. 1 in 23,204, the mortality in 117,078 cases of chloroform inhalation being 43 , i.e. 1 in 2723. M. Pétrequin of Lyons also states that for the fourteen years that ether has been exclusively given in that city, there has been no death from it ('Brit. Med. Journ.,' March $24,1866)$.

Dr. Richardson estimates the deaths from chloroform as 1 in 2500 ('Brit. Med. Journ.', October 1st, 1870, p. 356).

But there is another mode of estimating the relative danger of these two drugs, more reliable than statistics, that is, a 
consideration of their known effects, and of the relation of these effects to the chief dangers to be apprehended.

The committee appointed by this Society to investigate the use and effects of chloroform, report 109 fatal cases. In the 'British Medical Journal' for July 2, 1870, is a table of 18 more cases, and in an appendix to this paper I have given 13 others not included in either of those collections. An examination of these reports reveals two facts :-

1st. That in the majority of fatal cases the mode of death is by failure of the heart's action.

2nd. That this failure is generally sudden. This indeed is, I think, the only kind of death that would take place if the chloroform is given by one accustomed to its administration. For though of course I have often seen the respiration somewhat embarrassed under the inhalation of both chloroform and ether, I have never seen any real danger except from failure of the heart's action. In some of these cases I believe the effect on the heart has been produced by the shock of the operation, or by loss of blood; but in others it could be fairly attributed to nothing save the effect of the chloroform. In two cases of amputation at the hip-joint, for instance, $I$ have seen the patient in great danger from failure of the heart's action, but in both of these, the failure of the pulse was coincident with the removal of the limb. In the following case, however, the danger which arose could only be attributed to the chloroform, and as it seems to me typical of most of the dangerous or fatal cases, I here briefly relate it. The patient was a man aged 42 years, rather pale, but not in particularly weak health ; I had thrice before given him chloroform ; for the removal of a testicle, for amputation of the forearm, and for examination of the stump. On May 19th, 1871, I again gave him chloroform, using the modified Snow's inhaler. He had become insensible, and Mr. Holmes was proceeding to remove the carious end of the radius. I had removed the inhaler from his face for a short time, he was beginning to recover consciousness slightly, and the reflex sensibility of the eyelids had returned. I again applied the inhaler, which could not have contained more than half a 
drachm of chloroform, probably less; he then struggled slightly for about two minutes, and was becoming quiet, when his pulse suddenly stopped, without the slightest previous indication of failure. I instantly withdrew the inhaler and drew out the tongue; the respiration became very shallow and his face very livid, indeed, he was most nearly dead. Artificial respiration was at once resorted to, and after about three minutes, the pulse could be felt and he began to rally; the operation was proceeded with, and he recovered. This man had a regular, and rather weak pulse, and no discoverable heart disease. Having given chloroform to persons with extensive heart disease, and being accustomed to watch carefully the pulse as well as respiration, I can confidently state that, in this case, there was not the slightest indication of the approaching danger; the pulse ceased suddenly, and the patient was in a moment transferred from an apparently safe condition to one of the gravest danger.

The chief danger, then, from chloroform is a sudden arrest of the heart's action, and this danger does not pertain to ether. For it has been shown by Dr. Snow ('Anæsthetics,' p. 362) that it is impossible to paralyse the heart by ether inhalation; and the Chloroform Committee of this Society report that "its (ether) vapour may be regarded in a certain degree as a stimulant to the force of the heart's action" ('Med.-Chir. Trans.,' vol. xlvii, p. 335); and that the pressure in the vessels is maintained until there has been a manifest failure of the breathing (ibid.). The Committee also state (ib., pp. 346-7) that " the simple failure of respiration, whilst the circulation remains good, almost always betokens a recoverable condition," but that "the failure of the circulation to any considerable extent always involves extreme peril ;" and "after the heart has stopped, recovery is but just possible, and is by no means the usual result of attempts to resuscitate."

In the 97 cases in which I have given ether, I have uniformly found the pulse increased in volume, and the improvement maintained during the inhalation. On one occasion I gave ether to an old man of seventy-two, who 
had paralysis, from degeneration of the spinal cord, a very feeble heart, chronic bronchitis, and symptoms of uræmic poisoning. The operation of perineal section was performed while he was under the influence of ether, and the pulse was certainly stronger after, than before the operation.

Ether, therefore, has the advantage of being antagonistic to the effect of the shock of an operation.

Another advantage, I believe, of ether (though on this I speak less confidently for want of more extended experience) is that it is less liable to produce after-sicknèss than chloroform. It is necessary here to distinguish between the immediate, and the after-sickness produced by these vapours. If the stomach contains food, the inhalation of either ether or chloroform vapour will be equally liable to empty it. But chloroform sometimes produces a persistent vomiting, which comes on after its inhalation is finished, and which may cause even dangerous exhaustion. I do not think ether will cause this. In none of the cases in which $I$ have given it has there been any after-sickness in this sense of the word. To one child I gave it, in whom chloroform had twice produced after-sickness; but the ether had no such effect.

The chief objection that has been made to ether is the greater quantity, and therefore longer time, required to render a person insensible. This does not appear to me a very powerful objection; and, moreover, by attention to a few simple matters to which I will allude, insensibility can be produced almost as rapidly as by chloroform.

Of course, when ether is evaporated from any surface, the temperature of the surface is soon so much reduced as to materially interfere with its conversion into vapour. To obviate this, Dr. Snow kept his inhaler in a quantity of water, which was somewhat inconvenient. When I first began to give ether I therefore had two bell-shaped sponges, one of which was kept in hot water, while the other was used for the evaporation of the fluid; and these were changed when the temperature became sufficiently reduced to need it. But sponge is not a convenient material 
for the purpose, because it absorbs a large part of the ether, and gives it off from its outer surface; and, moreover, the ether is apt to gravitate to its lower part, and to run on to the patient's face, producing unpleasant cold or even blistering.

I have found the most convenient form of inhaler to be a cone of felt, covered with oiled silk or macintosh, into the upper part of which is fitted a piece of sponge, which can be changed occasionally for a similar piece kept in a basin of warm water. A shallow gutter running round the inside of the cone prevents the ether reaching the patient's face. An aperture, the size of which can be regulated by the finger, admits more or less air, as may be required.

By whatever kind of apparatus ether is administered, the principle of administration should be-

1. To scatter the ether on to a surface which allows its evaporation, without much absorption.

2. When the temperature of this surface is so much reduced that the ether is too slowly evaporated, to change it for a warm one.

3. To give the vapour freely at first, so as to bring the patient under its influence as quickly as possible, by which the tendency to struggling is lessened.

The two greatest inconveniences that $I$ have myself found to pertain to ether are, the unpleasantly noisy excitement sometimes manifested when the patient is recovering from its influence; and the rapid diffusion of the vapour about the room, which is, to some, disagreeable. The easy inflammation of the vapour must also be borne in mind.

I first gave ether on September 8th, 1870, at the suggestion of Mr. T. Smith, to a child, aged 3 years, in whom Mr. Smith closed a cleft in the hard and soft palate, while the child was under its influence. There was no difficulty in keeping the child completely insensible, which was done for fifty-five minutes. Two fluid ounces of the washed methylated ether were consumed. The child vomited a little swallowed blood at the time of the operation, but there was no after-sickness. I used the sponges for evaporating it. 
In two other cases, of the ages of nine and sixteen, I failed in keeping the patient quiet for a sufficient time after the withdrawal of the sponge from the face. This was, I believe, because I did not produce a sufficiently deep narcotism, and as ether when given on a sponge takes rather longer than chloroform to produce this, excepting in young children, it is not, I think, so well adapted as the latter, for operations upon the mouth where it requires to be readministered at intervals, as quickly as possible, and when, from hæmorrhage or other reasons, an inhaler cannot be used. I have, however, given it in six cases for the operation of cleft palate (in all of which, of course, Mr. Smith's gag was used), and in nine cases for other operations on the mouth, as puncturing the antrum, \&c. ; for excision of the elbow ; circumcision; lithotrity; lithotomy ; the application of nitric acid ; straightening contracted joints ; perineal section ; ligature of piles ; amputations, opening and examining joints ; plastic operations; iridectomy; removal of dead bone; removal of toenails, and other operations, in all without any bad symptoms (vide Appendix II).

I think it the more desirable to use an anæsthetic which has a stimulant, rather than a depressing, effect upon the heart, because I am convinced that anæsthetics do not so much lessen the shock of operations as has been by some asserted. Mr. Lister, in his article on "Anæsthetics," in 'Holmes' System of Surgery' (vol. iii, p. 93), goes so far as to say that both faintness and shock during an operation are got rid of by chloroform; and that an amputation under chloroform often improves the pulse. He also advises (ib., p. 105) the administrator of chloroform to disregard the pulse altogether. Great as is my respect for Mr. Lister's opinion, I feel bound to disagree with him on these points. I have given chloroform to more than 1300 persons, varying from three days to 78 years of age, and for almost every kind of operation, and have always carefully watched both pulse and respiration ; and have noticed almost invariably that the effect of any severe surgical operation has been to rapidly and markedly depress the heart's action. It is necessary to 
explain that I here speak of the pulse as it beats when the patient is fully narcotised. I fully believe in chloroform overcoming the effect of emotional depression; the pulse of a person is increased in rapidity, and lessened in force, by the fear and anticipation both of the operation and the anæsthetic ; and, as he becomes unconscious, the pulse improves, owing to the departure of fear with the occurrence of insensibility; but if we make the condition of pulse now present, our standard of comparison, I am confident that it is greatly and sometimes dangerously depressed by the shock of an operation. Besides this, I have not unfrequently had indications of danger from the pulse, which could not have been obtained from the respiration. I cannot, therefore, agree with Mr. Lister's advice to disregard this index.

It has been said that one great advantage of anæsthetics, is the mental tranquillity with which a person is enabled to regard the prospect of an operation which is to be robbed of its pain; but I am not sure that this is not often counterbalanced by the dread of an anæsthetic which it is known may of itself prove fatal. It seems to me, therefore, that for this, as for the other reasons I have herein advanced, we should, if possible, avail ourselves of an anæsthetic so safe as ether appears to be, rather than of one, however much it has to recommend it, to which is attached the danger which unquestionably pertains to chloroform. 
APPENDIX I.

Fatal cases of chloroform inhalation.

\begin{tabular}{|c|c|c|c|c|}
\hline No. & Date, authority, sex, age. & $\begin{array}{l}\text { Nature of } \\
\text { operation. }\end{array}$ & $\begin{array}{c}\text { Mode of } \\
\text { administration. }\end{array}$ & Mode of death. \\
\hline 1 & $\begin{array}{l}\text { Brit. Med.Journ., June 3, } \\
\text { 1865; Ophthalmic Hospital, } \\
\text { Bloomfield Street; male, æt. } \\
\text { 13. }\end{array}$ & Not stated. & Not stated. & Syncope. \\
\hline 2 & $\begin{array}{l}\text { Brit. Med. Journ., June } \\
\text { 24, 1865 ; Liverpool; child, } \\
\text { æt. } 2 .\end{array}$ & $\begin{array}{l}\text { Amputation } \\
\text { of finger. }\end{array}$ & \begin{tabular}{|} 
On lint; \\
thirty drops \\
given.
\end{tabular} & $\begin{array}{l}\text { Not stated ; “died } \\
\text { in five minutes.” }\end{array}$ \\
\hline $\mathbf{3}$ & $\begin{array}{l}\text { Brit. Med. Journ., March } \\
\text { 2, 1867; St. Mary's Hos- } \\
\text { pital; male. }\end{array}$ & $\begin{array}{l}\text { Reduction } \\
\text { of dislocation } \\
\text { of thumb. }\end{array}$ & $\begin{array}{l}\text { Clover's ap- } \\
\text { paratus; three } \\
\text { or four mi- } \\
\text { nutes. }\end{array}$ & Paralysis of heart. \\
\hline 4 & $\begin{array}{l}\text { Brit. Med. Journ., July 13, } \\
\text { 1867; Manchester Eye Hos- } \\
\text { pital; male, æt. } 8 .\end{array}$ & $\begin{array}{l}\text { For strabis- } \\
\text { mus. }\end{array}$ & Not stated. & Not stated. \\
\hline 5 & $\begin{array}{l}\text { Brit. Med. Journ., Septem- } \\
\text { ber 7, 1867 ; New York; } \\
\text { male, æt. 35. }\end{array}$ & Not stated. & On a towel. & $\begin{array}{l}\text { Not stated ; } \\
\text { "spasm in second } \\
\text { stage of narcotism." }\end{array}$ \\
\hline 6 & $\begin{array}{l}\text { Brit. Med. Journ., May 9, } \\
\text { 1868; Northern Hospital, } \\
\text { Liverpool. }\end{array}$ & Not stated. & Not stated. & Syncope. \\
\hline 7 & $\begin{array}{l}\text { Brit. Med. Journ., June } \\
\text { 13, 1868; Vienna ; male, } \\
\text { æt. 26. }\end{array}$ & $\begin{array}{l}\text { Ligature of } \\
\text { arteries in } \\
\text { wound of } \\
\text { hand. }\end{array}$ & Not stated. & $\begin{array}{l}\text { Heart stopped be- } \\
\text { fore respiration. }\end{array}$ \\
\hline 8 & $\begin{array}{l}\text { Brit. Med. Journ., Juue } \\
\text { 13, 1868; Hants County } \\
\text { Hospital; male, æt. 54. }\end{array}$ & $\begin{array}{l}\text { Ligature of } \\
\text { piles. }\end{array}$ & $\begin{array}{l}\text { On lint ; pa- } \\
\text { tient on left } \\
\text { side. }\end{array}$ & $\begin{array}{l}\text { Heart and respira- } \\
\text { tion ceased together. }\end{array}$ \\
\hline 9 & $\begin{array}{l}\text { Brit. Med. Journ., July } \\
\text { 25, 1868; Warley Lunatic } \\
\text { Asylum ; male, æet. 28. }\end{array}$ & $\begin{array}{l}\text { Amputation } \\
\text { of finger. }\end{array}$ & $\begin{array}{l}\text { On handker- } \\
\text { chief ; three } \\
\text { doses of } \\
\text { twenty } \\
\text { minims each. }\end{array}$ & $\begin{array}{l}\text { Heart paralysed ; } \\
\text { tubercle at base of } \\
\text { brain; heart and liver } \\
\text { fatty. }\end{array}$ \\
\hline 10 & $\begin{array}{l}\text { Brit. Med. Journ., March } \\
\text { 25, 1871 ; Salop Infirmary; } \\
\text { male. }\end{array}$ & For fistula. & \begin{tabular}{|} 
On lint; pa- \\
tient tarned \\
on to left side; \\
three and a \\
half drachms \\
used.
\end{tabular} & $\begin{array}{l}\text { Paralysis of heart; } \\
\text { organs healthy ; much } \\
\text { fat everywhere. }\end{array}$ \\
\hline
\end{tabular}




\begin{tabular}{|c|c|c|c|c|}
\hline No. & Date, authority, sex, age. & $\begin{array}{l}\text { Nature of } \\
\text { operation. }\end{array}$ & $\begin{array}{c}\text { Mode of } \\
\text { administration. }\end{array}$ & Mode of death. \\
\hline 11 & $\begin{array}{l}\text { Brit. Med. Journ., April } \\
29,1871 \text {; Swansea; male, } \\
\text { 47. }\end{array}$ & $\begin{array}{l}\text { Amputation } \\
\text { of leg. }\end{array}$ & $\begin{array}{l}\text { On lint; } \\
\text { three drachms } \\
\text { used. }\end{array}$ & $\begin{array}{l}\text { Failure of heart } \\
\text { and respiration. }\end{array}$ \\
\hline 12 & $\begin{array}{l}\text { Brit. Med. Journ., April } \\
\text { 22, 1871; Wilmslow, Che- } \\
\text { shire; male. }\end{array}$ & $\begin{array}{l}\text { Forcible ex- } \\
\text { tension of } \\
\text { knee. }\end{array}$ & Not stated. & $\begin{array}{l}\text { Not stated; it had } \\
\text { often been taken } \\
\text { before. }\end{array}$ \\
\hline 13 & $\begin{array}{l}\text { Edinb. Med. Journ., May, } \\
\text { 1871; Edinburgh Infirmary; } \\
\text { male, æt. 42. }\end{array}$ & $\begin{array}{l}\text { To reduce } \\
\text { dislocation of } \\
\text { humerus. }\end{array}$ & Not stated. & $\begin{array}{l}\text { Paralysis of heart ; } \\
\text { "fatty degeneration." }\end{array}$ \\
\hline
\end{tabular}

APPENDIX II.

Table of cases of ether inhalation.

\begin{tabular}{|c|c|c|c|c|}
\hline No. & Nature of operation. & Sex. & Age. & If after sickness. \\
\hline $\begin{array}{r}1 \\
2 \\
3 \\
3 \\
4 \\
5 \\
6 \\
7 \\
8 \\
9 \\
10 \\
11 \\
12 \\
13 \\
14 \\
15 \\
16 \\
17 \\
18 \\
19 \\
20 \\
21 \\
22 \\
23 \\
24 \\
25 \\
26 \\
27\end{array}$ & $\begin{array}{l}\text { Staphyloraphy. } \\
\text { Ditto. } \\
\text { Ditto. } \\
\text { Ditto. } \\
\text { Ditto. } \\
\text { Ditto. } \\
\text { Removing stitches from palate. } \\
\text { Ditto. } \\
\text { Ditto. } \\
\text { Amputation of thigh. } \\
\quad \text { " of fingers. } \\
\quad \text { of fingers. } \\
\text { Excision of elbow. } \\
\text { Removal of dead bone. } \\
\text { Ditto. } \\
\text { Ditto. } \\
\text { Ditto. } \\
\text { Ditto. } \\
\text { Ditto. } \\
\text { Ditto. } \\
\text { Ditto. } \\
\text { Ditto. } \\
\text { Ditto. } \\
\text { Ditto. } \\
\text { Ditto. } \\
\text { Ditto. }\end{array}$ & $\begin{array}{l}\text { F. } \\
\text { M. } \\
\text { F. } \\
\text { F. } \\
\text { F. } \\
\text { F. } \\
\text { F. } \\
\text { M. } \\
\text { M. } \\
\text { F. } \\
\text { F. } \\
\text { M. } \\
\text { M. } \\
\text { M. } \\
\text { M. } \\
\text { M. } \\
\text { M. } \\
\text { M. } \\
\text { F. } \\
\text { M. } \\
\text { M. }\end{array}$ & $\begin{array}{r}3 \\
16 \\
9 \\
3 \\
15 \\
14 \\
3 \\
3 \\
4 \\
48 \\
6 \\
8 \\
30 \\
24 \\
9 \\
3 \\
11 \\
6 \\
10 \\
6 \\
7 \\
8 \\
7 \\
8 \\
14 \\
10 \\
19 \\
6\end{array}$ & $\begin{array}{l}\text { No. } \\
\text { No. } \\
\text { No. } \\
\text { No. } \\
\text { No. } \\
\text { No. } \\
\text { No. } \\
\text { No. } \\
\text { No. } \\
\text { No. } \\
\text { No. } \\
\text { No. } \\
\text { No. } \\
\text { No. } \\
\text { No. } \\
\text { No. } \\
\text { No. } \\
\text { No. } \\
\text { No. } \\
\text { No. } \\
\text { No. } \\
\text { No. } \\
\text { No. } \\
\text { No. } \\
\text { No. } \\
\text { No. } \\
\text { No. }\end{array}$ \\
\hline
\end{tabular}




\begin{tabular}{|c|c|c|c|c|}
\hline No. & Nature of op:eration. & Sex. & Age. & If after sickness. \\
\hline 29 & Removal of dead bone. & M. & 8 & No. \\
\hline 29 & Ditto. & F. & 12 & No. \\
\hline 30 & Ditto. & M. & 9 & No. \\
\hline 31 & Incisions for periostitis of tibia. & M. & 17 & No. \\
\hline 32 & Applying nitric acid to leg. & F. & 30 & No. \\
\hline 33 & Ditto. & F. & 30 & No. \\
\hline 34 & Laying open the knee-joint. & F. & 20 & No. \\
\hline 35 & Ditto. & M. & 8 & No. \\
\hline 36 & Ditto. & M. & 7 & No. \\
\hline 37 & Ditto. & M. & 8 & No. \\
\hline 38 & Ditto. & F. & 17 & No. \\
\hline 39 & Laying open the hip-joint. & F. & 10 & No. \\
\hline 40 & Ditto. & F. & 7 & No. \\
\hline 41 & Opening abscess. & $\mathbf{F}$. & 10 & No. \\
\hline 42 & Ditto. & F. & 7 & No. \\
\hline 43 & Ditto. & M. & 8 & No. \\
\hline 44 & Ditto. & M. & 10 & No. \\
\hline 45 & Ditto. & F. & 10 & No. \\
\hline 46 & Ditto. & M. & 9 & No. \\
\hline 47 & Ștraightening hip-joint. & M. & 16 & No. \\
\hline 48 & ", knee-joint. & F. & 4 & No. \\
\hline 49 & Flexing elbow. & F. & 11 & No. \\
\hline 50 & Tenotomy. & F. & 11 & No. \\
\hline 51 & Ditto. & F. & 3 & No. \\
\hline 52 & Ditto. & F. & 6 & No. \\
\hline 53 & Ditto. & F. & 7 & No. \\
\hline 54 & Avulsion of toenail. & M. & 14 & No. \\
\hline 55 & Ditto. & F. & 19 & No. \\
\hline 56 & Circumcision. & M. & 2 & No. \\
\hline 57 & Ditto. & M. & $\mathbf{2}$ & No. \\
\hline 58 & Ditto. & M. & $1 \overline{1}$ & No. \\
\hline 59 & Ditto. & M. & 10 & No. \\
\hline 60 & Ditto. & M. & 5 & No. \\
\hline 61 & Ditto. & M. & 6 & No. \\
\hline 62 & Ditto. & M. & 7 & No. \\
\hline 63 & Sounding for stone. & $\mathbf{M}$. & 4 & No. \\
\hline 64 & Ditto. & M. & 10 & No. \\
\hline 65 & Lithotrity. & M. & 50 & No. \\
\hline 66 & Lithotomy. & M. & 3 & No. \\
\hline 67 & Removal of tumour of foot. & $\mathbf{F}$. & 15 & No. \\
\hline 68 & Puncturing antrum. & M. & 6 & No. \\
\hline 69 & Ditto. & M. & 6 & No. \\
\hline 70 & Syringing antrum. & M. & 6 & No. \\
\hline 71 & Ditto. & M. & 6 & No. \\
\hline 72 & Extraction of teeth. & F. & 9 & No. \\
\hline 73 & Ditto. & F. & 7 & No. \\
\hline 74 & Ditto. & M. & 6 & No. \\
\hline 75 & Laying opening sinus. & F. & 11 & No. \\
\hline 76 & Applying caustic to eyelid. & F. & 3 & No. \\
\hline 77 & Ditto. & F. & 3 & No. \\
\hline 78 & Ditto. & F. & $\mathbf{3}$ & No. \\
\hline 79 & $\begin{array}{l}\text { Examining eyes in strumous } \\
\text { ophthalmia. }\end{array}$ & F. & $\mathbf{3}$ & No. \\
\hline
\end{tabular}


16 ON ETHER AND CHLOROFORM AS ANASTHETICS.

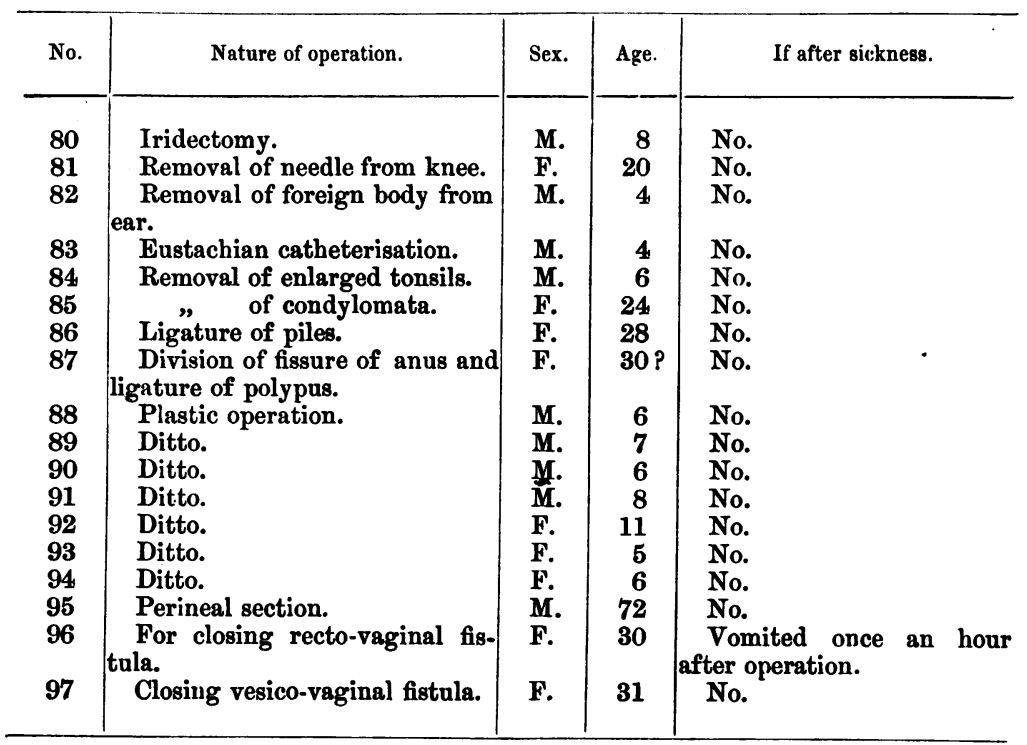

